\title{
Edukasi penyakit malaria dan pengobatan menggunakan obat herbal pasca gempa di Lombok
}

\author{
Windah Anugrah Subaidah ${ }^{*}$, Yohanes Juliantoni1, Wahida Hajrin ${ }^{1}$ \\ ${ }^{1}$ Program Studi Farmasi, Fakultas Kedokteran, Universitas Mataram, Mataram, Indonesia.
}

DOI: https://doi.org/10.29303/indra.v2i2.127

\section{Article Info}

Received : 15-08-2021

Revised : 30-09-2021

Accepted : 30-09-2021

\begin{abstract}
In September 2018 malaria was identified as an extraordinary event in NTB. Malaria plague spread in West Lombok. According to data from the West Lombok health service there were 184 cases. This includes pregnant women, children, and babies. Severe impact on vulnerable groups such as pregnant women and children. Pregnant women infected with malaria will experience severe anemia and have a higher risk of fetal death. In children, it affects the growth and intelligence disorders caused by anemia. The purpose of this community service was to increase the knowledge about malaria disease and ways to prevent it. The method is done by presenting the method, then followed by an interactive discussion and giving evaluation through post-test and pre-test. The service was carried out at the Senggigi village office in Batu Layar District, West Lombok Regency, West Nusa Tenggara Province. The contents of the presentation were what is malaria, how to prevent malaria, and how to use herbal medicine to cure malaria. Afterward, the committee distributed leaflets and abate powders to participants. The evaluation showed there was an increase in the knowledge of participants after education was given. The increase of knowledge about malaria would decrease the number of malaria cases at Senggigi village.
\end{abstract}

Keywords: education, malaria, Lombok.

Citation: Subaidah, W.A. (2021). Edukasi Penyakit Malaria dan Pengobatan Menggunakan Obat Herbal Pasca Gempa di Lombok. INDRA: Jurnal Pengabdian kepada Masyarakat, 2(2), 48-52. doi: https://doi.org/10.29303/indra.v2i2.127

\section{Pendahuluan}

Gempa yang mengguncang pulau Lombok menyebabkan 436 orang meninggal dunia dan kerugian ekonomi lebih dari Rp. 5.04 trilyun. Daerah yang terkena dampak gempa diantaranya yakni Kabupaten Lombok Utara, Lombok Barat, Kota Mataram, Kabupaten Lombok Timur. Kebanyakan korban masih tinggal di pengungsian atau mendirikan rumah semi permanen (Badan Nasional Penanggulangan Bencana, 2018). Lingkungan dan tempat tinggal yang buruk dapat berdampak pada kualitas kesehatan korban gempa. Kualitas kesehatan korban gempa yang menurun disebabkan beberapa faktor diantaranya minimnya air bersih dan buruknya sanitasi lingkungan (Widayatun, 2013). Kualitas kesehatan yang menurun dapat menyebabkan terjadinya berbagai penyakit yang menular. Salah satu penyakit menular yang sering muncul pasca terjadinya bencana adalah malaria (Khambali, 2017).

Malaria merupakan penyakit yang disebabkan oleh parasit Plasmodium. Parasit menyebar ke orang melalui gigitan nyamuk betina Anopheles. Spesies parasit yang menyebabkan malaria pada manusia yaitu P. falciparum, P. malariae, P. ovale, dan P. knowlesi. 2 diantaranya yang terbanyak dan terberat yaitu $P$. falciparum dan P. vivax (Ruiz et al., 2018). Parasit Plasmodium yang ditularkan oleh vector nyamuk akan bermigrasi ke hati host yang terinfeksi, kemudian masuk ke aliran darah dan menginfeksi sel darah merah. Masa inkubasi penyakit malaria kurang lebih 13 minggu (Bertolino et al., 2015). 
Penyakit malaria dapat menyerang semua golongan umur dari bayi, anak sampai dewasa. Dampak yang berat terjadi pada kelompok yang rentan, seperti ibu hamil dan anak-anak. Ibu hamil yang terinfeksi malaria akan mengalami anemia berat dan memiliki risiko lebih tinggi terhadap kematian janin. Pada anak-anak, malaria berdampak pada gangguan pertumbuhan dan kecerdasan yang disebabkan oleh anemia (Takem \& Alessandro, 2013).

Pada bulan September 2018 malaria ditetapkan sebagai kejadian luar biasa di NTB. Wabah malaria menyebar di Kabupaten Lombak Barat. Menurut data dari dinas kesehatan Lombok Barat tercatat sebanyak 184 kasus. Termasuk didalamnya ibu hamil, anak-anak dan bayi (Depkes RI, 2018).

Pengobatan malaria berdasarkan kebijakan nasional pengendalian malaria yakni dengan pemberian Artemisinin based Combination Therapy (ACT) (Depkes RI, 2017). Pemberian terapi dengan ACT sering kali tidak efektif karena terjadi resistensi terhadap obat yang diberikan serta timbulnya efek samping (Dimas Priantono et al., 2016). Oleh sebab itu, pencarian terapi yang efektif dan aman terus dilakukan. Salah satu terapi yang dapat digunakan adalah dengan penggunaan obat herbal. Penelitian terkait tanaman yang digunakan sebagai terapi anti malaria telah banyak dilakukan. Beberapa tanaman yang dapat digunakan untuk pengobatan malaria seperti sambiloto (Andrographis paniculata Nees), bandotan (Ageratum conyzoides [L.] L.), dan pepaya (Carica papaya L) (Indriaty et al., 2015).

Berdasarkan uraian tersebut maka diselenggarakan pengabdian kepada masyarakat dengan judul edukasi penyakit malaria dan pengobatan menggunakan obat herbal pasca gempa di Lombok. Tujuan pengabdian ini meningkatkan pengetahuan masyarakat tentang malaria dan bagaimana cara pencegahannya.

\section{Metode}

Metode pelaksanaan kegiatan untuk memecahkan masalah mitra terkait penyakit malaria terdiri dari beberapa tahapan yakni :

Tahapan persiapan sebelum dilaksanakan penyuluhan. Tahapan awal yakni pengurusan izin kepada pemerintah daerah. Selanjutnya melakukan koordinasi dengan sekretaris desa terkait lokasi dan pematangan susunan kegiatan. Koordinasi dengan aparatur setempat diperlukan guna kelancaran kegiatan pengabdian kepada masyarakat. Selanjutnya persiapan materi penyuluhan dalam bentuk power point tentang penyakit malaria dan pengobatannya menggunakan obat herbal. Materi penyuluhan terkait penyebab, bahaya, gejala, cara pencegahan dan pengobatan penyakit malaria. Selain itu diberikan pula materi pengobatan herbal menggunakan beberapa tanaman yang mudah diperoleh seperti sambiloto (Andrographis paniculata Nees), bandotan (Ageratum conyzoides [L.] L.), dan pepaya (Carica papaya L). Pembuatan materi pendukung lainnya yaitu berupa leaflet. Tujuan pembuatan leaflet adalah untuk untuk menambah pengetahuan masyarakat.

Tahapan pelaksanaan kegiatan. Pada tahapan ini tim pengabdian masyarakat memberikan edukasi tentang penyakit malaria dan pengobatannya secara tradisional. Pemberian edukasi dilakukan dengan cara memberikan penyuluhan tentang penyebab, bahaya, gejala, cara pencegahan dan pengobatan penyakit malaria menggunakan obat herbal. Penyuluhan dilaksanakan selama 30 menit diikuti sesi tanya jawab selama 15 menit. Pemberian materi dilakukan dengan menggunakan media power point dan leaflet malaria. Selain pemberian materi tim pengabdian juga membagikan bubuk abate dan memberikan petunjuk penggunaan bubuk abate.

Tahap akhir adalah evaluasi terhadap tingkat pengetahuan peserta. Penilaian dilakukan dengan memberikan lembar kuisioner yang terdiri dari 10 soal yang berhubungan dengan malaria. Kuisioner diberikan pada awal atau sebelum penyuluhan (pretest) dan setelah penyuluhan (post-test). Hasil evaluasi kemudian dianalisis untuk melihat keefektifan kegiatan pengabdian ini.

\section{Hasil dan Pembahasan}

Mitra pengabdian pada kegiatan pengabdian masyarakat ini adalah Desa Senggigi, Kabupaten Lombok Barat, provinsi Nusa Tenggara Barat. Desa Senggigi memiliki luas wilayah $1.703 \mathrm{Ha}$ terdiri dari 4 Dusun yaitu dusun Senggigi, Dusun Kerandangan, Dusun Loco dan Dusun Mangsit. Berdasarkan data survey penduduk tahun 2016, total penduduk di desa Senggigi berjumlah \pm 4,653 jiwa. Pada tahun 2018 dilaporkan terdapat 10 kasus malaria. Kegiatan pengabdian dilaksanakan di Kantor Desa Senggigi. Peserta penyuluhan yang hadir merupakan warga desa senggigi dengan data demografi seperti yang tersaji pada tabel 1 .

Persiapan awal kegiatan pengabdian dimulai dari pengurusan izin kepada pemerintah daerah. Seminggu sebelum pelaksanaan kegiatan, panitia berkoordinasi dengan sekretaris desa dalam mempersiapkan tempat serta kelengkapan pendukung lainnya.

Tabel 1. Demografi peserta penyuluhan

\begin{tabular}{ll}
\hline Variabel Demografi & \multicolumn{1}{c}{ Responden } \\
\hline $\begin{array}{l}\text { Rerata Umur } \\
\% \text { Pendidikan }\end{array}$ & $36,16 \pm 9,93$ tahun \\
Tidak tamat sd & $5,26 \%$ \\
Tamat SD/Sederajat & $36,84 \%$ \\
\hline
\end{tabular}




\begin{tabular}{ll}
\hline Tamat SMP & $26,32 \%$ \\
Tamat SMA/SMK & $31,58 \%$ \\
$\%$ Pekerja & \\
Bekerja & $26,32 \%$ \\
Tidak Bekerja & $73,68 \%$ \\
\hline
\end{tabular}

Kegiatan sosialisasi dimulai dengan
penyampaian tujuan kegiatan oleh dosen ketua kelompok keilmuan farmasetika. Tujuan dari kegiatan ini ialah memberikan informasi mengenai penyakit malaria, pencegahan dan pengobatannya menggunakan obat tradisional. Kegiatan kemudian dilanjutkan dengan pembukaan oleh kepala desa Senggigi. Setelah itu dilanjutkan dengan pemaparan materi mengenai malaria selama 30 menit diikuti dengan sesi tanya jawab selama 15 menit. Pemberian materi dilakukan menggunakan media power point. Selama sesi tanya jawab masyarakat terlihat antusias terhadap materi yang dipaparkan terlihat jelas dari banyaknya masyarakat yang memberikan pertanyaan terkait malaria dan pengobatannya.

Beberapa materi yang disampaikan selama penyuluhan di Desa Senggigi Lombok Barat tentang malaria antara lain adalah :

1) Definisi malaria yakni penyakit yang disebabkan oleh parasit Plasmodium. Parasit menyebar ke orang melalui gigitan nyamuk betina Anopheles.

2) Penularan penyakit malaria dapat terjadi disebabkan oleh gigitan nyamuk Anopheles betina, bawaan lahir dari ibu ke anak, yaitu penularan terjadi melalui tali pusat atau plasenta (malaria bawaan/congenital), jarum suntik, transfusi darah

3) Siklus penularan penyakit malaria

4) Bahaya penyakit malaria seperti dehidrasi, anemia, gagal organ tubuh. Pada ibu hamil dapat menyebabkan kematian janin dan pada anak menyebabkan gangguan pertumbuhan dan kecerdasan

5) Gejala malaria terdiri dari gejala awal dan gejala berat

6) Cara memastikan pasien menderita malaria

7) Pencegahan malaria

8) Pengobatan malaria menggunakan ACT (Artemisin Based Combination Therapy) dan cara meminum obat yang baik

9) Pengobatan menggunakan obat herbal. Tanaman yang dapat digunakan untuk mengobati malaria yakni sambiloto (Andrographis paniculata Nees), bandotan (Ageratum conyzoides [L.] L.) (Ukwe et al., 2010), dan pepaya (Carica papaya L.) (Kovendan \& Murugan, 2012). Tanaman-tanaman ini telah terbukti secara saintifikasi dalam mengobati malaria. Salah satunya sambiloto yang mengandung andrografolida, terbukti efektif menghambat pertumbuhan parasit malaria (Resi, 2014).
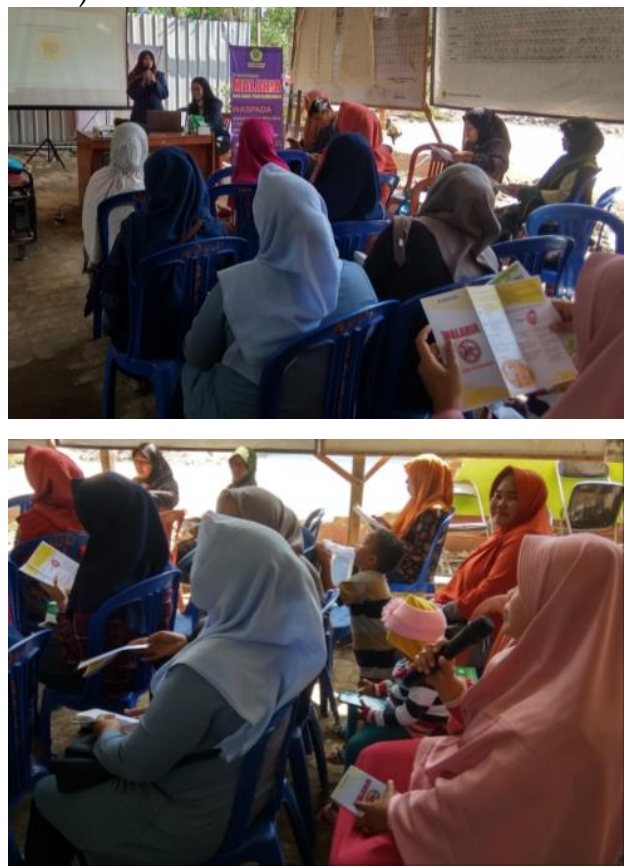

Gambar 1. Pemaparan materi tentang penyakit malaria, pencegahan dan pengobatannya

Selain pemaparan materi, tim pengabdian juga melakukan evaluasi terhadap peserta sosialisasi apakah terjadi peningkatan pengetahuan. Penilaian dilakukan dengan pengisian kuisioner sebelum (pretest) dan sesudah (post-test) kegiatan untuk mengetahui peningkatan pengetahuan warga. Kuisioner yang diberikan memuat pertanyaan yang berkaitan dengan penyakit malaria.

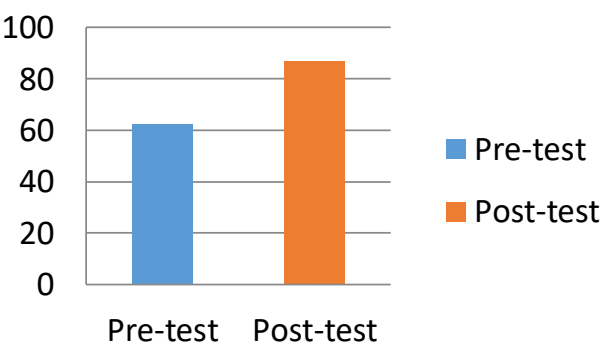

Gambar 2. Hasil evaluasi tingkat pengetahuan masyarakat terkait penyakit malaria.

Evaluasi terhadap peserta sosialisasi disajikan dalam gambar 2. Berdasarkan hasil evaluasi didapatkan nilai pre-test 62,63. Setelah diberikan sosialisasi dan pembagian leaflet nilai rata-rata post-test peserta menjadi 86,84 . Berdasarkan hasil perhitungan rata-rata pre-test dan post-test tersebut terlihat terjadi peningkatan poin sebesar 24,21.

Hasil evaluasi juga dianalisis menggunakan uji alternative Wilcoxon. Analisis dilakukan untuk 
mengetahui ada tidaknya perbedaan yang signifikan antara nilai pre-test dan post-test. Berdasarkan hasil analisis uji alternative Wilcoxon didapatkan nilai $\mathrm{P}$ value sebesar 0,001 lebih kecil dari 0,05. Hasil ini mengindikasikan terdapat perbedaan tingkat pengetahuan sebelum dan sesudah penyuluhan. Berdasarkan hasil perhitungan rata-rata pre-test dan post-test serta analisis statistik, dapat disimpulkan bahwa terjadi peningkatan pengetahuan pada masyarakat desa Senggigi sebelum dan sesudah diberikan sosialisasi.

Selain memberikan penyuluhan malaria, Tim pengabdian juga melakukan pembagian bubuk abate. Pembagian bubuk abate disertai petunjuk penggunaan bubuk abate yang baik dan benar.

Selama melaksanakan kegiatan pengabdian kepada masyarakat tidak ada kendala yang berarti, koordinasi dan komunikasi antara tim pengabdian dan desa mitra berjalan dengan baik. Kerjasama dan dukungan masyarakat yang baik ditunjukkan dengan animo masyarakat untuk menghadiri kegiatan sosialisasi. Dari hasil evaluasi dapat disimpulkan terjadi peningkatan pengetahuan masyarakat desa Senggigi terhadap penyakit malaria, pencegahan dan pengobatannya menggunakan obat herbal. Kegiatan sosialisasi tersebut merupakan sarana yang tepat dalam mengatasi masalah mitra. Diharapkan kedepannya kerjasama dengan mitra terus berjalan guna mengatasi masalah mitra.

\section{Simpulan}

Pelaksanaan pengabdian kepada masyarakat di Desa Senggigi tidak menemui kendala yang berarti. Koordinasi dan komunikasi antara tim pengabdian dan desa mitra berjalan dengan baik. Pengetahuan masyarakat terkait penyakit malaria meningkat hal ini ditunjukkan dengan peningkatan skor. Sebelum edukasi sebesar 62,63 meningkat 86,84 setelah edukasi.

\section{Daftar Pustaka}

Badan Nasional Penanggulangan Bencana Editorial. (2018, Agustus 15). Dampak Gempa Lombok: 460 Orang Meninggal Dunia dan Kerugian Ekonomi 7,45 Trilyun Rupiah. BNPB.

https://bnpb.go.id/berita/dampak-gempalombok-460-orang-meninggal-dunia460-dankerugian-ekonomi-745-trilyun-rupiah

Bertolino, P., Bowen, D. G., \& Cockburn, I. A. (2015). Malaria and the liver: immunological hide-andseek or subversion of immunity from within?. Frontiers In Microbiology. 6, 1-15.

https://doi.org/10.3389/fmicb.2015.00041
Kementerian Kesehatan Republik Indonesia. (2018, September 20). Upaya Kemenkes Atasi Malaria di Lombok Barat. Kementerian Kesehatan Republik Indonesia.

http://www.depkes.go.id/article/view/180920000 03/ministry-of-health-controls-malaria-in-westlombok.html

Departemen Kesehatan RI. (2017). Buku Saku Penatalaksanaan Kasus Malaria. Kementerian Kesehatan Republik Indonesia.

Dimas Priantono, Asep Purnama, E. J. N. (2016). Tantangan dalam Tata Laksana Malaria Berat di Rumah Sakit Daerah Terpencil di Indonesia. Jurnal Penyakit Dalam. 3(1), 41-44.

Indriaty, I., Bule, P., \& Tallan, M. M. (2015). Kajian Beberapa Tumbuhan Obat Yang Digunakan Dalam Pengobatan Malaria Secara Tradisional. SPIRAKEL: Sarana Penyebaran Informasi Hasil kegiatan Litbang. 7(2), 28-37. 10.22435/spirakel.v7i2.6125.28-37

Khambali. (2017). Manajemen Penanggulangan Bencana. Penerbit Andi.

Kovendan, K., \& Murugan, K. (2012). Antimalarial activity of Carica papaya (Family: Caricaceae) leaf extract against Plasmodium falciparum. Asian Pasific Journal Of Tropical Disease. 2(1). https://doi.org/10.1016/S2222-1808(12)60171-6

Resi, E. M. (2014). Effect of antimalaria herbal sambiloto (Andrographsi paniculata Nees) On Morphology Changes of Development and Parasite Plasmodium Falciparum. Jurnal Info Kesehatan, 12(1), 661-671.

Ruiz, A. O., Postigo, M., Casanova, S. G., Cuadrado, D., Bautista, J. M., Rubio, J. M., Luengo-Oroz, M., \& Linares, M. (2018). Plasmodium species differentiation by non - expert on - line volunteers for remote malaria field diagnosis. Malaria Journal, 1-10. https://doi.org/10.1186/s12936-018-2194-8

Takem, E. N., \& Alessandro, U. D. (2013). Malaria in Pregnancy. Mediterranean Journal Of Hematology And Infectious Disease, 5(1).

https://doi.org/10.4084/MJHID.2013.010

Ukwe, V. C., Epueke, E. A., \& Ekwunife, O. I. (2010). Antimalarial activity of aqueous extract and fractions of leaves of Ageratum conyzoides in mice infected with Plasmodium berghei Antimalarial 
activity of aqueous extract and fractions of leaves of Ageratum conyzoides in mice infected with Plasmodium bergh. International Journal of Pharmaceutical Sciences, 2(12), 33-38.

Widayatun. (2013). Permasalahan Kesehatan Dalam Kondisi Bencana: Peran Petugas Kesehatan Dan Partisipasi Masyarakat. Jurnal Kependudukan Indonesia, 8(1). 